\title{
The Awareness of Millennial Generation during Covid-19 Pandemic towards State Defense Character
}

\author{
Pingky Anggelia Wicahyanti ${ }^{1}$, Nur Annisa Rahim² ${ }^{2}$, Moses Glorino Rumambo Pandin ${ }^{2}$ * \\ ${ }^{1}$ Fakultas Ekonomi dan Bisnis, Universitas Airlangga, Surabaya, Indonesia \\ ${ }^{2}$ Fakultas Ilmu Budaya, Universitas Airlangga, Surabaya, Indonesia
}

\author{
*Corresponding Author: \\ Moses Glorino Rumambo Pandin \\ Faculty of Humanities, Universitas Airlangga \\ Jl. Dharmawangsa Dalam Selatan, Kampus B, Surabaya, 60286 \\ moses.glorino@fib.unair.ac.id
}

\begin{abstract}
Covid-19 has become a non-natural national disaster that affects the national resilience of the Indonesian state. In maintaining national resilience, the implementation of state defense is needed. This research aims to describe the awareness of defending the state of millennials during the current situation of the Covid-19 pandemic in Indonesia by using a quantitative approach with descriptive analysis methods with survey techniques. The results of this study indicate that most millennials are aware of the obligation to defend the state amid the current Covid-19 pandemic, namely by implementing health protocols such as preparing cleaning equipment, conducting social distancing, and working from home. However, there are still millennials who cannot run it for some reason. Based on the results of this study, it concluded that most millennials are aware of the obligation to defend the state during a pandemic by complying with health protocols as a form of state defense character.
\end{abstract}

Keywords: state defense, millennial, covid-19 pandemic, character

\section{INTRODUCTION}

Based on data from the Committee for Handling Covid-19 and National Economic Recovery, on March 2, 2020, for the first time, a positive case of Covid-19 was detected and announced in Indonesia. Since then, positive cases of Covid-19 have continued to grow and develop, on January 8, 2021, there were 808,340 positive cases of Covid-19 in Indonesia, where around 666,883 people were declared cured, and 23,753 died. Based on this explanation, Covid-19 can be said to be a non-natural disaster that is detrimental to people's lives, both eliminating the livelihoods of the 
affected community, disrupting the distribution and availability of community logistics, psychologically disturbing the condition of the community, even eliminating human lives (Samudro, 2020). In this regard, the government has also designated Covid-19 as a non-natural national disaster. Based on the national security of the Republic of Indonesia, it stated that the provisions of Law Number 24 of 2007 concerning National Disasters (Huljannah et al, 2020).

The conception of state resilience itself is an arrangement and implementation of welfare and security in a balanced, harmonious, and harmonious manner in all aspects of the life of the Indonesian nation to maintain Indonesia's national resilience. It is necessary to defend the state by citizens, following the Constitution of the Republic of Indonesia Article 27 paragraph (3) and Article 30 paragraph (1) regarding defense and security. In this article, it is explained that efforts to defend the state must be carried out by all Indonesian citizens without exception. This includes millennials or residents aged 15 to 34 years who are currently dominating the Indonesian population (Mukhtadi and Komala, 2018: 65) quoted from Kalfaris (2018: 72) millennials live in a modern and instantaneous era that causes them to become full-fledged individuals. Freedom, individualistic attitude, and active in the field of technology. This has caused the millennial generation to begin to forget the love of the Fatherland and State Defense, as stated by the Expert Staff of the Coordinating Minister for Political, Legal, and Security Affairs, Sri Yunanto in 2018..

The form of state defense itself has been regulated in Law Number 3 of 2002 concerning State Defense in article 9 paragraph (2) which states that efforts to defend the state are manifested in the implementation of state defense, including civic education, basic military service. Training, serving as the Army. Indonesian citizens are 
voluntary or obligatory, as well as their dedication in carrying out their profession (Widiyant, et al. (2019: 136). However, the current form of state defense is less shown by millennials because generally they prefer and are interested in the culture that comes. According to Samuel and Priyanto (2019: 162-175), the embodiment of the example of the millennial generation is influenced by technological developments that make it easier for them to access information so that their lifestyles tend to follow what they see. This is done to foster awareness of defending the country because the millennial generation uses learning methods related to their citizens with the use of technology (Suabuana et al, 2018: 39-41). The use of this technology can lead to several efforts to defend the state, as expressed by Pratiwi et al (2019: 70-75). According to him, the use of gadgets and the Internet by the millennial generation has the potential to combat threats arising from this technology ut. Thus, if information technology is used wisely and innovatively related to the integration of the Indonesian nation, millennials can imitate what they see every day on the internet and social media. Furthermore, millennials can also take advantage of technological developments for efforts to defend the country through IT-based business development and the use of social media to socialize social content that exhales Indonesia's potential and culture, especially during the Covid-19 pandemic. The act of developing an IT-based business during a pandemic and the use of social media for national content and socializing content regarding the importance of protocol can be said to be an effort to defend the country because these two actions are a manifestation of the value of defending the country, namely love for the country.

Based on this description can be concluded that efforts to defend the state have an important role in maintaining national defense during the Covid-19 pandemic. So 
that raises the question, "How big is the awareness of defending the country from the Indonesian millennial generation during the Covid-19 outbreak and the form of state defense being carried out?" Therefore, in this study the author will explain the amount of concern for the defense of the millennial generation during the Covid-19 pandemic.

\section{METHOD}

The research method used to answer this problem is a mixed-methods method (qualitative-quantitative). The qualitative approach is used with the literature study method, namely the collection of library materials and, the quantitative approach is used with the survey method, namely the making of a Google Form questionnaire.

This research was conducted online. The data collection stage begins with primary data collection. Primary data was obtained from a closed questionnaire using Google Form which was distributed online to 65 samples of the millennial generation involving $60 \%$ of students and $40 \%$ of the general public.

Then secondary data to support primary data is obtained from literature studies. Literature reviews were obtained from the Google Scholar database using the keywords "State Defense" "National Resilience", "Millennial Generation", and "Covid-19 Pandemic".

Data analysis was carried out using analytical description techniques used to collect material from questionnaires distributed about forms of state defense for the millennial generation during the Covid-19 pandemic. 


\section{RESULTS}

\section{Implementation of the Health Protocol as a Form of State Defense}

The Covid-19 outbreak has been designated as a non-natural national disaster that could threaten Indonesia's national resilience based on the provisions of Law Number 24 of 2007 concerning National Disasters (Huljannah et al, 2020). Quoted from Huljannah et al (2020) in the concept of state defense following Law of the Republic of Indonesia Number 3 of 2002 concerning State Defense Article 6 paragraph (1), "State defense is carried out through efforts to build and develop capabilities, strengths. country and nation, and to overcome every threat." In line with that, article 9 paragraph (1) states that "Every citizen has the right and obligation to participate in efforts to defend the state which are manifested in the implementation of state defense" which is further strengthened by paragraph (2), namely participation in state defense efforts in question is a form of state defense efforts that can be realized through civic education, basic military training, voluntary or compulsory service as the Indonesian National Army, and service according to their profession. Based on research conducted by Huljannah et al (2020), the application of health protocols to reduce the chain of the spread of the Covid-19 virus can be said to be an effort to defend the country in conditions of the Covid-19 pandemic, where the government makes regulations and the community implements it to create a sense of state defense and state resilience.

\section{Millennial Generation Defends State's Awareness in the Middle of a Pandemic}

Based on research involving 65 millennials, it is known that $98.5 \%$ of them are aware of their obligation to defend the country during the Covid-19 pandemic that has hit Indonesia. Table 1 shows the level of concern of the millennial generation as 
illustrated in figures 1-5. The number 5 shows a high level of concern and $50.8 \%$ of the respondents show this result. This means that the majority of respondents care about the current crisis conditions that are being experienced by Indonesia.Table 1.The level of concern of the millennial generation to defend the country during a pandemic

\begin{tabular}{c|c}
\hline Level of Care & Percentage \\
\hline Very Unconcerned & $0 \%$ \\
Unconcerned & $0 \%$ \\
Ordinary & $5 \%$ \\
Care & $44 \%$ \\
Very care & $51 \%$ \\
\hline
\end{tabular}

To overcome this, the Government of Indonesia issued a policy that everyone must apply social distancing. From the research results listed in Table 2, it can be seen that as many as $83.1 \%$ of respondents have implemented it, $15.4 \%$ of respondents sometimes apply it, and $1.5 \%$ have not.

Table 2. Percentage of Millennial State Defense Awareness through the Application of Social Distancing

\begin{tabular}{lc}
\hline Application of Social Distancing & Percentage \\
\hline Apply & $83.1 \%$ \\
Sometimes & $15.4 \%$ \\
Not Applying & $1.5 \%$ \\
\hline
\end{tabular}

Table 3 shows that $95.4 \%$ of respondents have provided medical devices in the form of hand sanitizers, hand wash, antiseptics, and masks at their respective homes as a 
form of COVID-19 prevention following government recommendations, while $4.6 \%$ have not prepared or had cleaning supplies.

In addition to social distancing policies, to implement a healthy lifestyle, the government also advised that all activities, both school, and work, be carried out from their respective homes. The analysis of Table 4 illustrates this. As many as $81.5 \%$ of respondents have carried out every activity from home, $15.4 \%$ still often leave the house, and as many as $3.1 \%$ always do their activities outside the home and cannot be replaced with online work from home. The study further discusses why these respondents are still frequently outside their homes during the current epidemic crisis because of the demands of their work to leave the house and cannot be replaced by the use of online media. The types of work referred to include small traders in traditional markets, masons, farmers, and construction workers. If they leave their jobs to stay at home, they will not have any income to support their families. Based on the results above, it appears that the Covid-19 pandemic is occurring not only in the health sector but also in the economic sector.

Table 3.Percentage of Millennials Providing Cleaning Equipment in Facing the Covid19 Pandemic.

\begin{tabular}{cc}
\hline Hygiene kits & Percentage \\
\hline Provide & $95.4 \%$ \\
Do not Provide & $4.6 \%$ \\
\hline
\end{tabular}

Table 4. Percentage of millennial generation who carry out activities from home. 


\begin{tabular}{cc}
\hline Activities from Home & Percentage \\
\hline Fully In Home & $81,5 \%$ \\
Sometimes outside & $15,4 \%$ \\
Fully outside & $3,1 \%$ \\
\hline
\end{tabular}

\section{Contribution of Millennial Generation in Efforts to Handle Covid-19 by the Government as a Form of State Defense}

Further research shows the form of the respondent's contribution to the handling efforts undertaken by the Indonesian government. The form of respondent's contribution can be seen in Table 5 which shows that $80 \%$ of respondents have the same perception, that staying at home is the best thing that can be done to support the government, while the other $20 \%$ have a different perception. Different forms of contribution include participating in online fundraising events, material contributions in the form of money and necessities (given to small communities affected by Covid), and medical devices (given to medical personnel who are experiencing a PPE crisis), there are also volunteers in activities spraying disinfectant in the area where they live, and wearing a mask when outside the home. The increasing need for masks is being used by tailors to produce masks to be sold to the public. However, some respondents showed their contribution by providing masks that were given to people who had economic limitations in particular so that they could stay healthy and meet the needs of masks for everyone. 
Table 5. Percentage of the contribution of the millennial generation to the government's efforts to overcome COVID-19

\begin{tabular}{lc}
\hline \multicolumn{1}{c}{ Contribution } & Percentage \\
\hline Stay at Home & $80 \%$ \\
Volunteer & $5 \%$ \\
Raising Funds & $5 \%$ \\
Participate in Charity activities & $7 \%$ \\
Others & $3 \%$ \\
\hline
\end{tabular}

\section{DISCUSSION}

Based on the results of analysis of literature data and survey data. It is known that implementing health protocols during a pandemic can be categorized as a form of state defense efforts that can be carried out by the Indonesian people during this pandemic, this is also supported by the words of DKI Jakarta Governor Anies Baswedan in an interview regarding March 19, 2020 (tirto.id). The results of the survey conducted also prove that most of the millennial generation have realized the importance of defending the country in the midst of the pandemic, although there are still a few who feel normal. Then the results of the study also showed as many as $81.1 \%$ of respondents had implemented social distancing in carrying out their activities. Positive results are also shown by research by Saputro et al (2020) which shows that most people have implemented social distancing. Apart from the application of social distancing, the community's attitude is also positive in implementing other health protocols such as providing cleaning tools and carrying out activities from home. 
However, the results obtained still show that there are still a small proportion of people who carry out work activities outside the home in full. As a fisherman, he is still active outside the house as usual.

Furthermore, the survey also shows that the form of the contribution of millennials as an effort to defend the country when a pandemic occurs is carried out in several ways, from the easiest, namely staying at home, then volunteering, raising funds for the community affected by a pandemic, and others.

These results show positive behavior and awareness of defending the country for millennials in Indonesia during a pandemic. However, it is hoped that a more in-depth study with a wider target population and respondents from other regions of Indonesia will demonstrate the accuracy of the results of this study.

\section{CONCLUSION}

Based on the results of this study, during the Covid-19 pandemic, the millennial generation shows high concern and makes a good contribution as a form of state defense to maintain national resilience and support the Indonesian government in its prevention and handling extraordinary event. Their contribution in defending the country is not only physically and energetically but also materially. With the characteristics of the online lifestyle, millennials have made good and wise use of technology even though they have to stay at home. Through social media, they hold a fundraising event which will later be given to the poor affected by Covid-19 and medical personnel who lack PPE (personal protective equipment). With the urgency of the current state of Indonesia, people are required to care for their nation and state. Therefore, efforts to defend the state are very important to be carried out to help the 
government and show love for the country, a harmonious relationship between the government and its people, and awareness of the obligations of the nation and state to every citizen.

\section{REFERENCES}

Cik Suabuana, dkk. (2018). Model Bela Negara Dalam Pendidikan Kewarganegaraan Pada Perguruan Tinggi Melalui Project Citizen. Jurnal Sosioreligi, 16. (1): 3442.

Hidayatullah, Syarif, dkk. (2018). Perilaku Generasi Millenial dalam Menggunakan Aplikasi Go-Food. Jurnal Manajemen dan Kewirausahaan, 6. (2):240-249.

I Nengah Suriata. (2019). Aktualisasi Kesadaran Bela Negara Bagi Generasi Muda Dalam Meningkatkan Ketahanan Nasional. Public Inspiration: Jurnal Administrasi Publik, 4( 1): 47-56.

Lalo, Kalfaris. (2018). Menciptakan Generasi Millenial Berkarakter dengan Pendidikan Karakter guna Menyongsong Era Globalisasi. Jurnal Ilmu Kepolisian, 12 (2) :68-75.

Mardhia, D., Kautsari, N., Syaputra, L. I., Ramdhani, W., Rasiardhi, C. O. 2020. Penerapan Protokol Kesehatan Dan Dampak Covid-19 Terhadap Harga Komoditas Perikanan Dan Aktivitas Penangkapan. Indonesian Journal of Applied Science and Technology. 1(2): 80-87.

Mukhtadi' dan R. Madha Komala. (2018). Membangun Kesadaran Bela Negara Bagi Generasi Milenial dalam Sistem Pertahanan Negara. Jurnal Manajemen Pertahanan, 4(2): 66-83.

Pratiwi, Anggi dan Eflinnida Nurul K.A. (2019). Implementasi Literasi Budaya dan Kewargaan Sebagai Solusi Disinformasi pada Generasi Millenial di Indonesia. Jurnal Kajian Informasi dan Perpustakaan, 7( 1): 65-80.

Rahayu, dkk. (2019). Kesadaran Bela Negara Pada Mahasiswa. Jurnal Epigram, 16 (2): $175-180$.

Samuel, Tahan dan Priyanto. (2019). Evaluasi Pembinaan Kesadaran Bela Negara Masyarakat di Kota Tangerang. Jurnal Abdimas UPJ 2(2): 162-175.

Saputro, A. A., Saputra, Y. D., Prasetyo, G. B. 2020. Analisis Dampak Covid-19 Terhadap Kesadaran Masyarakat dalam Penerapan Protokol Kesehatan. Jurnal Pendidikan Jasmani Kesehatan dan Rekreasi. 3(2): 81-92.

Setiawan, R. 2020. Cegah COVID-19, Anies: Bela Negara Caranya Bertahan di Rumah. https://tirto.id/cegah-covid-19-anies-bela-negara-caranya-bertahan-di-rumaheGrn. Diakses pada 2 Mei 2021.

Soepanji, Kris Wijoyo dan Muhammad Farid. (2018). Konsep Bela Negara Dalam Perspektif Ketahanan Nasional. Jurnal Hukum dan Pembangunan, 48 (3): 436456.

Wahyudi. (2017). Peran Kader Bela Negara di Kawasan Perbatasan dalam Dinamika Hubungan Lintas Batas Negara: Studi Tentang Peran Forum Bela Negara di Sebatik, Kabupaten Nunukan, Provinsi Kalimantan Utara. Jurnal Pertahan dan Bela Negara, 7 (3): 19-40. 
Widiyanto, Delfiyan dan Annisa Istiqomah. (2019). Pembinaan Kesadaran Bela Negara Melalui Budaya Sekolah. Jurnal Pendidikan Kewarganegaraan, 3(2): 133-143. 